\title{
The Chechens and Kurds of Kazakhstan between Historical and Second Homelands
}

\author{
Beate Eschment | ORCID: 0000-0002-4287-1125 \\ Researcher, ZOiS (Centre for East European and International Studies), \\ Berlin, Germany \\ beate.eschment@zois-berlin.de
}

\begin{abstract}
Almost all minority ethnic groups in Kazakhstan are immigrants. This means that in addition to their current place of residence, Kazakhstan (their "Second Homeland"), they also have a place of origin (their "Historical Homeland"). The leadership of the country has approached this situation, which offers opportunities as well as dangers, by explicitly exhorting the official ethnic representations of minorities to nurture contacts with their Historical Homelands. In this article the examples of the Chechens and Kurds will be used to show how the representations of both ethnicities actively and politically pursued this task. For both groups, representing a nation without an independent state, a fourth actor must be added to the "triangle nexus" familiar from diaspora studies, respectively Russia and Turkey, whose positions the Kazakhstani government cannot simply disregard. What emerges from the study is the strong emotional link of both minorities' representatives with Kazakhstan as their Second Homeland.
\end{abstract}

\section{Keywords}

Kazakhstan - Chechens - Kurds - nationalities - diaspora - identity - Homeland

Kazakhstan is a multiethnic state. Almost all of its minority ethnicities have migrated to the country at various times and for various reasons, most of which were forced deportees under Stalinism. As a result, they find themselves with ties not only to Kazakhstan as the country where they now live ('host state', in Kazakhstan: 'Second Homeland'), but also to the place from which they or 
their ancestors emigrated ('kin state', in Kazakhstan: 'Historical Homeland'). Having links to two homelands can, in general, bring both positive and negative effects, not only for the people concerned, but also for the states. ${ }^{1}$ It can encourage political and economic contacts abroad or provoke conflicts of interest.

In Kazakhstan, for example, Kazakh nationalists made unfounded accusations of disloyalty against their non-Kazakh fellow citizens soon after independence. By contrast, the leadership of the country in the mid-199os founded the 'Kazakhstani' model of civic identity and not only encouraged the non-Kazakh populace to form ethnocultural organizations, but also explicitly called on them to forge and maintain contacts with their Historical Homelands. At first, such contacts were largely unregulated and informal, but it soon became clear that they also brought problems. There were cases, for instance, of attempted harassment of one ethnicity by another through the activities of their Historical Homeland. There were also instances of members of particular ethnicities presenting themselves like official representatives of their kin state. Restrictions were therefore quickly imposed and, over the two decades since, these restrictions have intensified in every respect, mainly as a natural result of the growing authoritarianism $^{2}$ in the country.

The nature and intensity of individual ethnicities' contacts with their Historical Homelands thus prove not only to be important in assessing the position of ethnicities within Kazakhstan and the Kazakh government's policy on nationalities, but also to be relevant from a foreign and security policy perspective. The problems of transnational contexts have repeatedly become apparent in recent years through the case of the Uyghurs. Yet, the attentions of the security authorities have also been focused on the Chechens and Kurds, although nothing has come to light regarding the reasoning behind this. ${ }^{3}$ Both ethnicities have a Historical Homeland ridden with problems and struggling to assert its statehood. In the case of the Chechens, although their homeland is

1 William Safran, 'Diasporas in Modern Societies, Myths of Homeland and Return', Diaspora 1 (1991)1, 83-99, 92-3.

2 On the rise of authoritarianism in Kazakhstan, see for example: Bhavna Dave, Kazakhstan. Ethnicity, language and power, (London New York: Routledge 2007); Natsuko Oka, 'Managing Ethnicity under Authoritarian Rule: Transborder Nationalisms in Post-Soviet Kazakhstan', IDE Interim Report, 2007, https://www.ide.go.jp/library/Japanese/Publish/Download/Report/ pdf/20o6_04_31_all.pdf; Aleksandra Jarosiewicz, 'Perestroika—the Nazarbayev way. Crisis and reforms in Kazakhstan', OSW Point of View, 58, June 2016, https://www.osw.waw.pl/sites/ default/files/pw_58_perestroika-the-nazarbayev-way_net.pdf; Kate Mallinson, 'Governance', Kazakhstan. Tested by Transition, Chatham House Report Nov. 2019, 10-22.

3 Kurdskaia problema Kazakhstana, ili Za chto diuzhinu Kazakhstantsev lishili grazhdanstva, Fergananews, 14.9.2007, https://www.fergananews.com/articles/535o (no longer available). All Internet sources accessed at 29.1.2021. 
an undisputed part of the Russian Federation today, it was the theatre of two brutal wars over independence from Russia in the 1990s. The Kurdistan that the Kurds of Kazakhstan regard as their Historical Homeland today extends across the territories of four states, within each of which Kurds fight to establish their own nation-state, or at least autonomy, which touches on keen sensibilities in Turkey in particular. ${ }^{4}$

The initial premise of this study is that this unusual situation, which distinguishes Chechens and Kurds from most other ethnicities, has an impact on the political relationship between the ethnicities and the state of Kazakhstan, as well as on their identification of the homeland. This study therefore begins by describing relations between the Chechens and Kurds (i.e., their official representations), their respective Historical Homelands, and the reactions to those in Kazakhstan. The study then goes on to establish their relationship with their Historical Homelands and with the Second Homeland in which they now live.

\section{Definitions and Concepts}

Although politicians and representatives of ethnicities alike frown upon the term 'diaspora' in Kazakhstan today, there is no doubt that analytical approaches of diaspora studies are applicable to many of the country's ethnicities. Some adaptations, however, are needed. In the case of the ethnicities under discussion here, the kin state's lack of statehood poses a problem not only for those involved, but also in analysis because scholarship has yet to take account for such a possibility. Not only does the discipline of diaspora studies in general use the term 'state', but also the investigation of diasporas by Brubaker and King after the demise of the Soviet Union only took account of nationalities that now had a new and independent home state. ${ }^{5}$ Studying the Chechens and Kurds therefore requires the replacement, as is usual in Kazakhstan, of the word 'state' with 'land', which carries no connotation of

4 The destinies of the Chechens and Kurds has also been interwoven by the fact that Russia and Turkey have pursued mutually antagonistic foreign policies by supporting the ethnicity living in the other state. Cf. Robert Olson, 'The Kurdish Question and Chechnya: Turkish and Russian Foreign Policies Since the Gulf War', Middle East Policy Council, 4, 3, March 1996, https://mepc.org/node/4813; Fatma Asli Kelkitli, Chapter 5, Sensitive spots: Chechen and Kurdish matters, Turkish-Russian Relations, (London: Routledge 2017), 77-85.

5 Rogers Brubaker, 'National Minorities, Nationalizing States, and External National Homelands in the New Europe', Daedalus, 124, 2, Spring 1995, 107-132; Charles King, Introduction: Nationalism, Transnationalism, and Postcommunism, Nations Abroad. Diaspora Politics in the Former Soviet Union, eds. Charles King, Neil J. Melvin, (New York, London: Routledge 1998), 1-25. 
statehood. ${ }^{6}$ Furthermore, the triadic nexus-the reciprocal triangular relationship between diaspora, host state, and kin state-must be made tetragonal to include the foreign power in whose territory the Historical Homeland of the Chechens and Kurds lies.

The reference to homeland plays a categorically vital role in the ethnic discourse of Kazakhstan. Eventually, relationships with countries of origin and Kazakhstan become points of discussion in virtually all conversations with members of smaller ethnicities. For the reasons explained above, these discussions do not use the terms 'home/kin state' or 'host state', but 'Historical' and 'Second (or sometimes 'Small') Homeland.' Despite their frequent use, there does not seem to be a definition of these terms specific to Kazakhstan. Even a new ethnopolitical lexicon of Kazakhstan, for instance, makes 'state' the fundamental category, defining 'Historical Homeland' as the state to whose titular nation a person belongs by birth (i.e., a hereditary affiliation), regardless of the actual place of birth or the individual relationship with a state. ${ }^{7}$ 'Small Homeland' is accordingly defined as the place of birth and residence of a person as personality, with an emphasis on the fact that cultural influences of this current place of residence will have an impact on identity. ${ }^{8}$ The following definitions of the terms as used today are distilled from these lexicon entries and from many conversations with members of various ethnicities and Kazakhstani experts. 'Historical Homeland' is the place-located in the near or distant past and often emotionally charged to the point of mysticism - where an ethnicity's migration began. In the case of the Germans of Kazakhstan, for instance, this is not the place from which they were deported in 1941, but Germany, which in some instances their ancestors left more than two centuries ago. Despite such remoteness, an inherited connection is assumed. The 'Second' or 'Small Homeland' is Kazakhstan, the place of birth, with its living conditions and mentality, which are regarded as formative. Those who use this term seek to express a deep connection that goes far beyond the more neutral term 'host state.'

In this way, the concept of homeland used in Kazakhstan differs from that of Western science today, which, for all the differences between disciplines, views the homeland as constructed and changeable. This does not assume an inherited and thus indissoluble bond to a homeland, as in the Kazakhstani understanding, but an endeavour to preserve or even create a place that emotionally represents belonging, memory, and localisation, which is 'intimately

6 Brubaker does use the term 'homeland', but uses it in reference to states.

7 Etnosayasi Sözdik/Etnopoliticheskii slovar, ed. E. Togzhanov (Astana: no publisher given, 2014), 258.

8 Ibid., $272-3$. 
integrated into the human psyche. ${ }^{9}$ Home is therefore a project and product of people that changes in the course of their lives and through encounters with other places. ${ }^{10}$ In particular, the (traumatic) experiences of forced migration lead to the idealisation of the lost homeland, which, at the same time, becomes a unifying element of ethnic identity. In this concept of home, memory and longing are brought together in such a way that they become a place of security and well-being." ${ }^{11}$ The homeland discourse does not develop in free space but is influenced by power relations and elites that define standards of loyalty and make the boundaries of belonging seem immutable. ${ }^{12}$

\section{Research and Methods}

The smaller ethnicities of Kazakhstan only belatedly came to the attention of Western researchers. However, there are some publications that examine issues of transnationality and the importance of historical homelands. ${ }^{13}$ Chechens and Kurds in independent Kazakhstan, however, have received almost no attention in the West thus far. ${ }^{14}$ Even surveys and compendia treat them only superficially in a few sentences. ${ }^{15}$ They receive more attention in Kazakhstan, but with the main focus on history and culture. As with other ethnicities, these

9 Alexander Diener, One Homeland or Two? The Nationalization and Transnationalization of Mongolia's Kazakhs, (Washington D.C., Chicago: Woodrow Wilson Center Press; Stanford UP: 2009), 17.

10 Rita Sanders, 'Zwischen transnationaler Verstörung und Entzauberung: Kasachstandeutsche Heimatkonzepte', Zuhause? Fremd? Migrations- und Beheimatungsstrategien zwischen Deutschland und Eurasien, (Bielefeld: transcript Verlag 2015), 293-314, 296-7.

11 Ibid., 299.

12 Diener, 19.

13 Alexander Diener, 'Homeland as a Social Construct:Territorialization among Kazakhstan's Germans and Koreans', Nationalities Papers 34, 2006, 2 May, 201-235; A.C. Diener, 'Transnationalism and Minority Territorialization in Kazakhstan', International Journal of Central Asian Studies, 2006 11, 86-102; Natsuko Oka, 'Transnationalism as a Threat to State Security? Case Studies on Uighurs and Uzbeks in Kazakhstan', ed. T. Uyama, Empire, Islam and Politics in Central Eurasia, Sapporo 2007, 351-368; Natsuko Oka, 'The "Triadic Nexus" in Kazakhstan: A Comparative Study of Russians, Uighurs, and Koreans' Osamu Ieda (ed.), Beyond Sovereignty. From Status Law to Transnational Citizenship, (Sapporo: Hokkaido University 20o6), Slavic Eurasia Studies 9, 359-380.

14 The main focus of Birgit Brauer's article 'Chechens and the survival of their cultural identity in exile', Journal of Genocide Research 2002, 4(3), 387-400 is on memories of deportation. The only publications about the Kurds deal with the Soviet period. Most recently J. Otto Pohl, 'Kurds in the USSR', 1917-1956, Kurdish Studies, 5(2017)2, 157-171.

15 E.g., Amjad M. Jaimoukha, The Chechens: A Handbook (London, New York: Routledge, 2005); Martin Strohmeier, Lale Yalcin-Heckmann, Die Kurden. Geschichte, Politik, Kultur (Munich: C.H. Beck, 2017). 
publications tend to be self-portraits published by the ethnocultural organizations, written by each organization's (former or current) chairperson or-in the case of the Kurds - a scholar of Oriental studies. Although the Chechens have an account written by an outsider in the form of a monograph by a Kazakh scholar, ${ }^{16}$ even it is constrained-as all recent discussions of interethnic issues are- by such factors as official language usage and fears of breaking laws that caution against heightening interethnic tensions. As a Kazakh scholar wrote in 2010, 'It has long been taboo in Kazakhstani media-and society in general — to publicly discuss problems related to interethnic relations. ${ }^{17}$ The same applies to scholarship. Self-censorship appears only to have intensified in recent years.

This situation informs the present study. My interviewees' willingness to talk about problems and conflicts was in short supply. At the same time, because little is known about Chechens and Kurds in independent Kazakhstan, and because events are glossed over in retrospect, it has been necessary to make meticulous reconstructions of the events and positions described on the basis of materials preserved on the internet. Only texts in Russian were used here, since it is the language of interethnic communication. The purpose of this study is not to pursue intraethnic debates but to present the actions and public image of both ethnicities in Kazakhstani politics and society (i.e., in their interethnic context). For the same reason, the focus of the study is limited to representatives of the ethnocultural organizations who bear responsibility for these tasks in the Kazakhstani nation-building concept. ${ }^{18}$

Diaspora studies are interdisciplinary. ${ }^{19}$ As a result, this paper relies on a mix of methodologies. First, this study relies on semi-structured interviews with different generations of spokespeople of both ethnicities' ethnocultural organizations, undertaken in the autumn of 2018 and early $2019,{ }^{20}$ in addition to observer participation at events. Augmenting this are several expert interviews, conducted at Almaty and Astana/Nur-Sultan. The paper also draws on discourse analysis (e.g., to examine the self-testimonies of the chairpersons of the national associations).

16 Z.A. Ermekbaev, Chechentsy i ingushiv Kazakhstane, (Almaty: Daik Press 2009).

17 Dinara Tussupova, 'Mass Media and Ethnic Relations in Kazakhstan', Problems of Post Communism 57 (2010)6, 32-45, 33.

18 Yves-Marie Davenel, Eunsil Yim, 'Minority Assimilation and Nation-Building in Kazakhstan', Nation-Building and Identity in the Post-Soviet Space. New Tools and Approaches, ed. Rico Isaacs, Abel Polese, (London, New York: Routledge 2016), 46-64, 47.

19 Kim D. Butler, 'Defining Diaspora, Refining a Discourse', Diaspora. A Journal of Transnational Studies, 10 (2001) 2, pp. 189-219, 212.

20 Sadly, COviD-19 meant the cancellation of follow-up interviews. 


\section{The Chechens}

Chechens living in the Republic of Kazakhstan today are the survivors of the 1944 deportation of the entirety of the Chechen nation. Chechens were sent to the Kazakh SSR along with their descendants, as well as a smaller cohort of migrants from the latter part of the Soviet period. The last Soviet census, taken in 1989, recorded 49,007 Chechens living in the Kazakh ssR. A wave of migration to Chechnya followed the collapse of the UssR. By 1999, the Republic of Kazakhstan had only around 32,0oo citizens of Chechen nationality. The official figure for 2020 was $33,500 .{ }^{21}$ The Chechens count among the 20 numerically strongest ethnicities in the country. ${ }^{22}$

Today, around $50 \%$ of all Chechens live in the countryside, often in compact settlements. There is frequent mention of the village of Krasnaya Polyana, $300 \mathrm{~km}$ northwest of Nur-Sultan, and two neighbouring villages, with populations that are almost entirely Chechen. These groups uphold the Chechen language, customs, and traditions. ${ }^{23}$ As a whole, the economic position of Chechens is regarded as positive. ${ }^{24}$ Many appear already to have found their economic niche during the Soviet period. After independence they adapted rapidly to the conditions of the market economy. Large-scale Chechen entrepreneurs operating in the grain industry, for example, are found in the Akmola oblys, northwest of the capital Nur-Sultan. Chechens are heavily represented in commerce and the building sector in towns and cities.

Most Chechens are bilingual (Russian and Chechen). Those in the south often also speak Kazakh quite well. However, knowledge of Chechen may be

21 Natsional'nyi sostav, veroispovedanie $i$ vladeniia iazykami v Respublike Kazakhstan. Itogi Natsional'noi perepisi naseleniia 2009 goda v Respublike Kazakhstan, Astana 2010, https://stat.gov.kz/api/getFile/?docId=WC1620o032705; Chislennost' naseleniia Republiki Kazakhstan po otdelnym etnosam na nachalo 2020 g., https://www.stat.gov.kz/api/ getFile/?docId=ESTAT 355258 .

22 According to Russian data, 1,206,551 Chechens now live in Chechnya (95.3\%). Another 250,00o live elsewhere in the Russian Federation, and a historical diaspora of about 100,00o live in Turkey, with smaller groups across the Near East and a growing group of Chechens exiled in the West, stated for Europe at 150,ooo people in 2016. Cf. 'Chechen Diaspora Suffers as West Seeks Common Ground With Moscow on Fighting Terrorism', EDM, 29.9.2016, https://jamestown.org/program/chechen-diaspora-suffers-west-seeks -common-ground-moscow-fighting-terrorism/.

23 Liudi zikra: kak zhivut potomki deportirovannykh chechentsev, 5·3.2018, https://www. bbc.com/russian/features-43261824; Memories of the Chechen exodus, 23.2.2017, https:// eurasianet.org/kazakhstan-memories-of-the-chechen-exodus-dont-fade.

24 Konrad-Adenauer-Stiftung, Zusammenleben ethnischer Gruppen in Kasachstan, Almaty 2017/18, 63, https://www.researchgate.net/publication/323571799_Zusammenleben _ethnischer_Gruppen_in_Kasachstan. 
decreasing. ${ }^{25}$ Like the Kazakhs, the Chechens are Muslim, but they belong to the Shafi'i legal school (whereas virtually all other Muslims in Kazakhstan are Hanafites). Sufi brotherhoods are of great importance. Many reports agree that Chechens have preserved their own traditions and values to this day, associated with a certain degree of self-isolation. Their behaviour is described as follows: they limit their contacts with the rest of society to the absolutely unavoidable minimum. They are also the least acculturated and assimilated ethnicity in Kazakhstan. ${ }^{26}$

There have been several violent conflicts between Chechens and locals, both in the Soviet period and in the Republic of Kazakhstan. ${ }^{27}$ The most serious of recent times occurred in March 2007 in the villages of Malovodnye and Kasatkom near Almaty. A dispute between young Chechen and Kazakh billiards players mushroomed into violent confrontations between members of both ethnicities, causing five deaths and ending in Kazakh demands for the expulsion of Chechens. ${ }^{28}$ Such demands were not new. Reaction to the murder of four Kazakhs by a Chechen in the Ust'-Kamenogorsk oblast' in 1992 resulted in the issuing of an edict of expulsion (which was later rescinded) by the local authority. ${ }^{29}$ As many interviewees (who wish to remain anonymous) in Kazakhstan confirm, Chechens, in general, have a poor reputation. The only disagreement concerns whether this is a result of Russian media reporting and the terror attacks perpetrated by Chechens in several places around the world, or whether the negative image came about directly in Kazakhstan.

The first ethnocultural organisation for Chechens was founded in Almaty in 1989. There are now ethnocultural centers in all oblystar of Kazakhstan. In accordance with their official purpose, they offer language courses and often run dance ensembles, dedicating themselves to Chechen history and culture. Vainakh, the national association promoting the culture of the Chechen-Ingush, ${ }^{30}$ was founded in 1995 . The president of its Chechen section, Akhmet Muradov, was a deputy sent to the Kazakhstani Parliament (Mazhilis)

25 Adam Boisaev in an interview with the author, Almaty, 24.9.2018. Because the census has now been postponed twice, there is no current official information on language knowledge, educational status, etc. for the ethnicities of Kazakhstan. Recourse must therefore be made to statements by their representatives.

26 Ermekbaev, Chechentsy, 279, 324.

27 Nurtai Mustafaev, O tom, kak zhivetsia chechentsam v Kazakhstane, Central Asia Monitor, 6.3.2015, https://camonitor.kz/15517-o-tom-kak-v-kazahstane-uzhivayutsya-chechency-ikazahi.html.

28 Joanna Lillis, Socio-Economic Tension Threatens Kazakhstan's Ethnic Harmony, 3.4.2007, https://eurasianet.org/socio-economic-tension-threatens-kazakhstans-ethnic-harmony.

29 Tschetschenen droht Vertreibung aus Kasachstan, Süddeutsche Zeitung, 21.10.1992.

30 See: http://www.vainahkrg.kz/. 
by the Assembly of the People of Kazakhstan (ANK) for the Fifth (2012-2016) and Sixth legislative periods (2016-2021).

\section{The Trauma of Deportation and Its Consequences}

The Chechens (and Ingush) were deported en masse as a nation to Kazakhstan (and Kyrgyzstan) under appalling conditions on February 23, 1944. The Chechen-Ingush ASsR was subsequently abolished. ${ }^{31}$ No exact numbers exist, but it is estimated today that about 500,000 people were exiled. Only half are believed to have survived deportation and their early years as 'special settlers' in the Kazakh SSR. ${ }^{32}$ The Supreme Soviet's restoration of the ASSR and the associated lifting of the ban on returning home in 1957 triggered a mass migration. Of the 524,000 Chechens and Ingush previously living in the Kazakh sSR, only 56 ,ooo had, for various reasons, not returned home by $1963 .{ }^{33}$

These events brought a series of consequences that continue to resonate in Kazakhstan today. Memory of the deportation is regarded as an important and formative component of the identity of all Chechens and is regularly invoked. Chechens in Kazakhstan regularly mark February 23rd as a memorial day with events and publications. A delegation from Chechnya usually attends these events. ${ }^{34}$ Accounts of brutal experiences are numerous. The trauma of deportation appears to have provoked an anti-Soviet and anti-Russian attitude among most Chechens. It is also regarded as one of the triggers for the First Chechen War. ${ }^{35}$ However, it has had no negative impact on the Chechen-Kazakh relationship. Efforts are made in this respect to uphold the deportees' gratitude for Kazakh assistance, which enabled their survival.

Even when most Chechens returned to the Caucasus, very close relations persisted. These manifested themselves not only in visits in both directions,

31 For more detail, see Nikolai Bugai, 'Pravda o deportatsii chechenskogo i ingushskogo narodov', Voprosy istorii 7/199o, pp.31-44; Campana Aurélie, 'The Massive Deportation of the Chechen People: How and why Chechens were Deported', Mass Violence and Resistance Research Network, 5.11.2007, https://www.sciencespo.fr/mass-violence-war -massacre-resistance/en/document/massive-deportation-chechen-people-how-and -why-chechens-were-deported.html; Nicolas Werth, 'The "Chechen Problem": Handling an Awkward Legacy, 1918-1958', Contemporary European History, Vol. 15, No. 3 (Aug. 2006), 347-366, https://www.jstor.org/stable/20081316.

32 Akhmet Muradov interviewed by the author, Astana, 17.9.2018.

33 Ermekbaev, Chechentsy. 268.

34 Ibid., 340.

35 Brian Glyn Williams, 'Commemorating "The Deportation” in Post-Soviet Chechnya', History and Memory 12(200)1, 101-134. 
but also migrations. ${ }^{36}$ The biography of the current president of Vainakh is not atypical. Akhmet Muradov was born in 1951 to Chechen special settlers in a village in Kustanai oblast'. His family returned to the restored Chechen ASSR in 1957. Muradov completed his schooling and university studies there. He then moved to Mangyshlak in Kazakhstan in 1977 to work as an oil engineer and, when Kazakhstan became independent, he began to advocate in support of Chechen interests. ${ }^{37}$ Relations are still close today, demonstrated through regular visits. Around $8 \circ \%$ of Chechens in Kazakhstan are believed to own (inherited) property in Chechnya. ${ }^{38}$ Naturally, they also follow events in Chechnya on television and online.

Another consequence of deportation is that almost all Chechens involved in the First Chechen War, in particular, were born in Kazakhstan and/or spent some years of their childhood there. Former presidents, Aslan Maskhadov and Akhmat Kadyrov, for example, were still small children when their families returned, while Dzhokhar Dudaev arrived in Kazakhstan as a newborn and spent the first 13 years of his life there. Ruslan Khasbulatov was born in Grozny in 1942 and was deported to Kazakhstan in his infancy, remaining there until moving to Moscow to begin his university studies. Mufti Mukhamed-Khusein Alsabekov only returned to Grozny after the fall of the Soviet Union, becoming Grand Mufti, Minister for Islam, and advisor to the president there.

\section{The Challenge of the Chechen Wars}

Given such close connections, the Chechen Wars posed enormous challenges both to the Chechens of Kazakhstan and to the state of Kazakhstan itself. In 1994, at a time when the economic situation in Kazakhstan was very fragile, the Chechen cultural centers, acting out of 'patriotism and solidarity with the people of Chechnya, ${ }^{39}$ sent several large humanitarian aid consignments to the war zone. Furthermore, the Chechen-Ingush cultural centre, Vainakh, also became politically active. As 'the largest and best organised' group of Chechens abroad, ${ }^{40}$ it took the initiative of launching a peace mission (Maslaat), scarcely conceivable today and ultimately fruitless, involving

36 Ermekbaev, Chechentsy, 273. The memorial in Chechnya between 2012 and 2019 took place at the behest of Ramzan Kadyrov on 10 May, the anniversary of the day in 2004 when his father was assassinated.

37 Cf. http://www.parlam.kz/ru/mazhilis/person/15o1 (no longer available).

38 Boisaev interview.

39 Nasha obshchaia zadacha-edinenie i sokhranenie mezhnatsional'nogo miraAssotsiatsiia 'Vainakh', 2.5.20o9, https://www.zakon.kz/58894-nasha-obshhaja-zadacha -edinenie-i.html.

Ibid. 
members of the diaspora from near and far, as well as Chechen clerics and intellectuals. Its members are believed to have met several times with Chechen leadership under Dudaev, opposition leaders (R. Khasbulatov; U. Avturkhanov), and high-ranking officials of the Russian Federation. In an interview with the official Kazakhstanskaia pravda, the then president of Vainakh declared an unequivocal position, against the Russian Federation, in which-despite all the failings on the Chechen side-he identified the deep-seated causes of the conflict. He emphasised that Chechens had the right of self-determination and that their decision to secede from the Russian Federation was legitimate. ${ }^{41}$ Speaking to the Russian Nezavisimaia gazeta, the Vainakh leader even called Russian activities in Chechnya a 'criminal plot.42 In addition to negotiations in Chechnya itself, countless appeals were also sent on the initiative of Vainakh to (Kazakhstani) President Nursultan Nazarbaev and (Russian) President Boris Yeltsin with demands and peace proposals. Statements were issued to the parliaments of the world, the UN, the OSCE, and OIC calling, among other things, for the withdrawal of Russian forces.

Meanwhile, hostilities in Chechnya were causing a wave of refugee movements, which affected Kazakhstan, the 'natural magnet for fleeing Chechens', ${ }^{43}$ so severely that the issue began to dog international relations. Those arriving were not officially recognised as refugees and received neither state aid nor permission to work. They therefore relied on support from relations living in Kazakhstan and from the national cultural centers. Air links between Kazakhstan and the northern Caucasus were temporarily suspended to hinder their migration. ${ }^{44}$ Estimates of the numbers affected range from 15,00o to 25, ooo. Most returned home after the signing of the peace accord between the Russian Federation and Chechnya in 1996. ${ }^{45}$

The situation recurred in the autumn of 1999, when the bombardment of Grozny marked the outbreak of the Second Chechen War. Once again, several thousand Chechens sought refuge, mostly arriving illegally by ship across the Caspian Sea, in Kazakhstan, 'the only place besides Chechnya where they can feel at home. ${ }^{46}$ However, they found themselves even less welcome than five years before. The Kazakhstani government found itself in a dilemma, having,

\footnotetext{
41 Chechnia: kogda v politikakh soglasiia net, Kazakhstanskaia pravda, 1.11.1994.

42 Chechenskii krisis glazami kazakhstanskoi diaspory, Nezavisimaia gazeta, 11.1.1995.

43 Amanchi Gunashev, Almaty Shuns Chechen Refugees, 14.1.20oo, https://iwpr.net/global -voices/almaty-shuns-chechen-refugees.

44 OMRI announcement, 26.3.1996.

45 Chechens Receive No Welcome, RFE/RL 9.12.1999, https://www.rferl.org/a/1092883.html; Amanchi Gunashev, Almaty Shuns.

46 Ibid.
} 
on the one hand, lent its support to the Russian Federation in the war against terror in November 1999 and, on the other hand, being a signatory to the Geneva Convention Relating to the Status of Refugees, which obliged it to recognise and assist the Chechens. The decision was clearly made to follow foreign-policy priorities: the refugees were not recognised. Young men in particular were arrested and interrogated, some were deported to Russia and Kazakh media portrayed them as potential terrorists. Others found themselves, without work or a place to live, having to survive with the support of local Chechens. The predicament of the Kazakh leadership worsened further on November 13, 2002, when 300 Chechen families, facing a fourth winter in a camp in Ingushetia, wrote to Presidents Nazarbaev and Vladimir Putin, requesting asylum in Kazakhstan. Nazarbaev immediately declared their problems to be an internal matter for his strategic partner, Russia, but the matter became so controversial that it appeared on the agenda of a meeting between Nazarbaev and Putin in Moscow. ${ }^{47} \mathrm{Up}$ to 20,000 Chechen refugees are said to have been in Kazakhstan in 2002. ${ }^{48}$ According to its own evidence, the UNHCR was still supporting about 5,000 Chechen refugees in Kazakhstan in the summer of $2006 .{ }^{49}$

It is also an open secret in Kazakhstan that Chechens from Kazakhstan fought in the wars in Chechnya. Their official representatives have also confirmed this. ${ }^{50}$ There are no details, however, of the numbers involved (or the numbers killed). Kazakhs also emphasise that Chechens never took up arms on Kazakh territory and that fighters returned to normal civilian life on their return.

\section{Normalisation of Relations?}

The history of the relationship between the Republic of Kazakhstan and the Chechen Republic has not yet been written. President Nursultan Nazarbaev is said to have lodged highly personal official protests against the First Chechen War. ${ }^{51}$ During the second war, if not before, Astana stood shoulder to shoulder

47 'Might a "Self-Deportation" of Chechens to Kazakhstan ensue?', 3.12.2002, https://james town.org/program/might-a-self-deportation-of-chechens-to-kazakhstan-ensue/; 'No solution for Chechen refugees in Kazakhstan', 23.12.2002, https://reliefweb.int/report/ russian-federation/no-solution-chechen-refugees-kazakhstan.

48 Missiia nevypolnima? 21.11.2002, https://www.ng.kz/gazeta/34/online/?oo1.

49 Helping Chechens back on their feet in Kazakhstan, UNHCR 16.8.2006, https://www .unhcr.org/news/latest/2006/8/44e311ce2/helping-chechens-feet-kazakhstan.html.

50 Muradov in Drugaia Chechnia, 4.12.2000, https://www.neweurasia.info/archive/200o/ ru_press/12_04_410.htm, Adam Boisaev in interview.

$5^{1} \quad$ Nasha obshchaia zadacha. 
with the Kremlin, distancing itself by insisting that the war was an internal matter for the Russian Federation. Efforts also seem to have been made to ensure that the Chechen representatives in Kazakhstan saw things in the same way.

Early in the incumbency of the present Chechen leader, Ramzan Kadyrov, ties were close. A housing project financed by the government of Kazakhstan was built in Grozny in 2007. A street in the city centre has been renamed Ulitsa Nursultana Nazarbaeva and a school has also borne the name of the First President since 2010.52 Most significantly, in June 2007, just one month after taking office, Kadyrov made a state visit to Kazakhstan, during which he was also received by Nazarbaev. ${ }^{53}$ It was at this point, too, that the convention of diplomatic language was established that still applies now. Following bilateral meetings, the Chechen side emphasised its good relations with Kazakhstan and the Kazakhstani side celebrated its own with the Russian Federation. A memorial to the father of the current presidency, the assassinated ex-president Ahmad Kadyrov, was unveiled in the Karagandy oblys in 2012, apparently without high-ranking guests from Chechnya. Kadyrov, as is well known, has remained unusually active in foreign relations for a provincial governor (visiting Uzbekistan, for instance, in 2017), but he seems to have not returned to Kazakhstan. He has not, however, tired of declaring his special connection with Kazakhstan, invariably reminding listeners that his murdered father was born there. ${ }^{54}$

Representatives of the Chechens of Kazakhstan have taken part, not only in the events of 2007, but also in ensuing contacts on a parliamentary level, at conferences, visits by economic delegations, and more. As described, Vainakh, in the 199os, conducted its own foreign policy and very clearly adopted an antiRussian position. However, it also voiced cautious criticism of happenings in Chechnya. As late as 2009, Akhmad Muradov, an important figure in interstate contacts as the president of Vainakh, explicitly criticised Russian actions in the first war, but had only positive words for Kazakhstan and Kazakhstani

$5^{2} \quad$ Lyceum No.1 of Grozny named after Nursultan Nazarbayev, 15.4.2010, https://www.inform. kz/en/lyceum-no-1-of-grozny-named-after-nursultan-nazarbayev_a2258377.

53 President Nursultan Nazarbayev Receives President Ramzan Kadyrov of the Chechen Republic, 4.6.2007, http://www.akorda.kz/en/events/president-nursultan-nazarbayev -receives-president-ramzan-kadyrov-of-the-chechen-republic.

54 Cf. e.g. Ramzan Kadyrov: I have a special attitude towards Kazakhstan, Kazakhstanskaia pravda, 1.3.2019, https://kazpravda.kz/en/news/society/ramzan-kadyrov-i-have-a-special -attitude-towards-kazakhstan. Marlene Laruelle points out that the close relations between Chechnya and Kazakhstan depend on the close personal relationship between a highranking Kazakh, Kenges Rakishev, and Kadyrov. Marlene Laruelle, Kadyrovism. Hardline Islam as a toll of the Kremlin, Notes de l'Ifri. Russie.Nei.Visions, March 2017, 26, https:// www.ifri.org/sites/default/files/atoms/files/rnv99_m._laruelle_kadyrovism_en_2017.pdf. 
behaviour. ${ }^{55}$ In April 2012, Muradov was in Grozny for the first time as a deputy of the parliament of Kazakhstan. Neither at this event, nor any other of its type since, has he uttered a single critical word regarding the Russian Federation or Chechnya. Of the latter, for instance, he praises its effective governmental administration, its competent parliament, its mobile government, and its economic recovery. ${ }^{56}$ Furthermore, in retrospect, he finds that there have never been problems for Chechens in Kazakhstan and that Nazarbaev intervened in support of the war refugees. Furthermore, he reiterates that the Kazakhs were delighted to welcome them. ${ }^{57}$ Naturally, in all his remarks concerning the deportation, Muradov also follows the official narrative of gratitude that has prevailed in Kazakhstan for some years: Chechens only survived their first years in the steppes thanks to the help they received from the Kazakhs and they will be eternally grateful to them for this.

\section{Where Is the Homeland?}

Without a doubt, the Chechens of Kazakhstan have a powerful emotional and practical attachment to Chechnya, which they call their Historical Homeland. Yet, this clearly has no impact on their relationship with Kazakhstan and the possibility of resettlement.

Ramzan Kadyrov explicitly called upon the Chechens of Kazakhstan to return to the Caucasus in 2011 and promised them support with integration. While they had all the conditions for a good life in Kazakhstan, he argued that no other country could replace their historical homeland. ${ }^{58}$ Demographic trends alone show that Kadyrov's call went largely unheard. The number of Chechens in Kazakhstan has been slowly increasing over the past decade. Clearly, the allure of the Historical Homeland is slight, even in times of peace. There are occasional quotations in which younger generations express a yearning for Chechnya, ${ }^{59}$ but many also show that younger people, while still deeply attached to Chechen values and traditions, have often, and in growing

55 Nasha obshchaia zadacha.

56 A. Muradov: Kogda chechentsam khorosho u sebia doma, im khorosho vezde, 9.4.2012; http://vestig5.ru/2012/04/135189/.

57 Akhmet Muradov, sopredsedatel' assotsiatsii chechentsev in ingushei Kazkahstana 'Vainakh': My liudi bez vrednykh privychek, 26.10.2016, https://time.kz/articles/chastnyj/ 2016/10/26/ahmet-muradov-sopredsedatel-associacii-chechencev-i-ingushej-kazahstana -vajnah-mi-ljudi-bez-vrednih-privichek.

$5^{8}$ 'Kadyrov pozval chechentsev zhivushchikh v Kazakhstane na rodinu', Diapazon, 29.4.2011, https://diapazon.kz/news/210o8-kadyrov-pozval-chechencev-zhivushhikh-v.

59 Joanna Lillis, Dark shadows. Inside the secret world of Kazakhstan, (London, New York, I.B. Tauris) 2019, 153 . 
numbers, never been to Chechnya and show no desire to do so. ${ }^{60}$ The head of the Chechen ethnocultural association of Almaty, Adam Boisaev, formulates the position of younger generations as follows: 'I don't want to emigrate to Chechnya - why should I? Who am I there? My friends are here, I'm doing well here.' ${ }^{\prime 1}$ Even Vainakh chairman, Muradov (b. 1951), declares, 'It's one thing to feel the Historical Homeland as history, and quite another to live out the dream of returning to that Historical Homeland and to be looking back over your shoulder all the time.' ${ }^{62}$ He clearly speaks in favour of staying in Kazakhstan, although the freedom to identify as a Chechen without restriction is an absolute condition. The possibility of maintaining close contacts with Chechnya is also important to him, as is the principle, even if never acted upon, of being able to emigrate.

For many Chechens, the Historical Homeland is clearly more of a destination for visits. It is a place to spend limited time, from which they wish or long to return to Kazakhstan. For older generations, this may be because the many changes that would preclude their feeling quite at home, ${ }^{63}$ or for others because they would feel less safe in Chechnya. Other factors mentioned include rejection of the current regime, fear of other clans, and unemployment. Kazakhstan offers better living conditions, peace, and stability. ${ }^{64}$

Kazakhstan is also frequently referred to not as 'Second Homeland', but simply as homeland. A Chechen woman reports that she loved being in Chechnya, but continues, 'Even so, to speak honestly, my homeland, Kazakhstan, is closer to my heart.'65 'Our home is here now. Our graveyard is here. We've put down roots here', declares another. ${ }^{66}$ In many statements, the crucial criterion for connection to one's homeland is one's place of birth. 'A person should love the earth on which he is born. He loves it because it is his homeland', explains

6o Liudi zikra: Kak zhivut potomki deportirovannykh chechentsev, 5.3.2018, https://www. bbc.com/russian/features-43261824.

61 Boisaev interview.

62 Muradov interview.

63 Ermekbaev, Chechentsy, p. 286.

64 Konrad Adenauer Stiftung, Zusammenleben, 63-65.

65 'Nam net tuda vozvrata'. Kak zhivut v Kazakhstane deportirovannye v 1944 godu chechentsy i ingushi, Nastoiashchee vremia, 23.2.2019, https://www.currenttime.tv/a/chechens -ingushes-kazakhstan/29785669.html.

66 Aishat Khalimova, head of the only all-Chechen school outside Chechnya. Caption below the teacher's photograph: Little Chechnya on the Steppes. Photos by Oliver Bullough and Cicely Fell, undated, probably Feb. 2014, https://www.bbc.co.uk/programmes/po1zc8oo/ poiz782p. 
Muradov to those contemplating leaving. ${ }^{67}$ Boisaev says, 'Your homeland is where you were born. I was born here. And for me, the Chechen Republic is my Historical Homeland. ${ }^{68}$ At the same time, he acknowledges an indissoluble (hereditary) tie to Chechenness per se. He considers Chechen identity genetic and asserts that his relationship to any Chechen will be different from his relationships to other people.

Ermekbaev is therefore undoubtedly correct in stating that the Chechens of Kazakhstan have a dual identity as Chechens and citizens of Kazakhstan. ${ }^{69}$ Despite all the symbolic significance of the Historical Homeland Chechnya, the growing time gap since the deportation, as well as the possibility of directly comparing conditions in the Historical and Second Homeland, have led to the current preference for the latter.

\section{The Kurds}

The Kurds came to Kazakhstan in three waves. Unlike the Chechens, under Stalin deportation was not imposed on the entire national population, but only on those living along the Turkish border. This fate befell those living in the Armenian and Azeri SSR in 1937 and, in 1944, members of various nationalities, including Kurds living along the Georgian border were deported to Kazakhstan. There are no exact figures for how many were affected. Like all other numerical assessments regarding Kurds in the territory of the former Soviet Union, this information is still unclear and disputed, but 553 deported families are mentioned for $1937 .^{70}$ According to Bugai, ${ }^{71} 40,000$ people were forcibly resettled in Kazakhstan from Georgia in 1944, but the statistics are not broken down by nationality. Neither the rescission of the special regulations governing forcibly deported nationalities, nor the break-up of the USSR triggered a wave of re-emigration. On the contrary, between 1988 and 199o, Kazakhstan became a place of refuge for Kurds compelled to leave Armenia and Azerbaijan by the conflict over Nagorno-Karabakh. ${ }^{72}$

67 Muradov interview. During an interview in Grozny in 2012, however, he expressed pride in his Chechen homeland and called it home. Muradov: Kogda chechentsam khorosho.

68 Boisaev interview.

69 Ermekbaev, Chechentsy, 285; 333.

70 Pohl, 'Kurds', 163.

71 N.F. Bugai, 'Etnicheskoe men'shinstvo kurdov v natsional'noi politike Soiuza SSR- Rossii: 1920-1990-e gody', Etnopanorama 1-2, 2015, pp. 4-14, p. 10.

72 There are no exact figures available here either. Overall, it is believed that 18,ooo Muslim Kurds were expelled from Armenia, and 2,ooo Kurds had to leave Azerbaijan. Most 
According to official figures, about 46,ooo Kurds are living in Kazakhstan today, but the Kurds themselves claim that the figure is closer to 100,000. According to them, many Kurds have sought to avoid persecution by declaring themselves to be Azeri. Even if the official figures are accepted, the Kurdish population has been steadily increasing within the Kazakhstani population over recent decades. In early 2020 , the Kurds were in 12 th position of the 100 or more nationalities present in the country. ${ }^{73}$

After deportation, most Kurds settled in the south of Kazakhstan and their population is still mostly concentrated in the Almaty, Turkestan, and Zhambyl oblystar. According to the 2009 census, they were mainly ( $75 \%)$ living in the countryside, to some extent in compact settlements. However, the percentage living in towns is believed to have increased to $50 \%$ in recent years. ${ }^{74}$ In the countryside, many of them worked in livestock farming and in towns in small and medium-sized enterprises, especially cafes, restaurants, and shops. ${ }^{75}$ Although some publications refer with pride to Kurdish members of the scholarly elite, the data from the 2009 census shows that only an extremely small percentage of university graduates were Kurds. At the same time, the 2009 census data shows the Kurds, linguistically speaking, as the best equipped of all ethnicities in the country, with a high level of trilinguality. Since then, the number of Kazakh-speaking Kurds is believed to have risen to more than $75 \%{ }^{76}$ Knowledge of Kurdish, however, is declining. ${ }^{77}$ Virtually all Kurds in Kazakhstan are Sunni Muslims, like the Kazakhs.

Like almost all other ethnicities, the Kurds have their own ethnocultural organisation. The first one was founded quickly after the end of the Soviet period, registered officially in the Republic of Kazakhstan under the name Jakbun ('Unity') in 1993 and renamed Barbang ('Burgeoning', 'Blossoming') in 1999. It has ten branches today. Its activities resemble those of other cultural

appear to have gone to the Russian region of Krasnodar. See: David McDowall, The Kurds. Minority Rights Group, 1996, 36, https://minorityrights.org/wp-content/uploads/old-site -downloads/download-865-Download-full-report.pdf. According to my interviewees in the Republic of Kazakhstan, however, there is a substantial number of resettled Kurds in Kazakhstan today, including the current chairman of the Kurdish Association in the country, Knyaz' Mirzoev.

73 Chislennost' naseleniia Republiki Kazakhstan po otdelnym etnosam na nachalo 2020 g., https://www.stat.gov.kz/api/getFile/?docId=ESTAT 355258 .

74 Vakil Nabiev interviewed by the author, Almaty, 24.9.2018.

75 Nadir Nadirov, 'Kurdy ochen' khorosho ladiat s kazakhami i ne ispytyvaiut nikakikh pritensiy', Central Asia Monitor, 13·3.2015, https://camonitor.kz/15608-nadir-nadirov-kurdy -ochen-horosho-ladyat-s-kazahami-i-ne-ispytyvayut-nikakih-pritesneniy.html.

76 Knyaz' Mirzoev, Kurdy na perekrestrakh istorii, vol. 1, (Almaty: Ulagat, 2016), 306.

77 Knyaz' Mirzoev interviewed by the author, Almaty 18.3.2019. 
centers: language courses (Kurdish and Kazakh), dance and music groups, events to mark events in Kurdish history and official Kazakh public holidays, and the running of the society's own Kazakh and Russian-language media. ${ }^{78}$ Jakbun was one of the first members of the Assembly of People of Kazakhstan (ANK). ${ }^{79}$ For the first time, the ANK elected a Kurd, Vakil Nabiev, as its parliamentary deputy in January 2021.80

Barbang representatives insist that the situation for Kurds in Kazakhstan is unproblematic and that they are well-adapted, integrated, and equal citizens. The former president of Barbang even declared in 2015 that the relationship between Kurds and Kazakhs was uniquely close. 'They (the Kazakhs, B.E.) are closer to us than to the other peoples living in the republic.'81 He cited as evidence knowledge of languages and commonalities in culture, habits, traditions, and religion. Personal impressions, less recent opinions and at least one incident, however, give good reason to doubt at least the notion of unusually good relations. My conversations with various citizens of Kazakhstan frequently elicited negative stereotypes about Kurds (criminals, drug dealers, etc.), and I was assured that Kurdish youths kept apart from others and formed their own, Kurdish-speaking gangs. ${ }^{82}$ Dominating the picture, however, is the violent confrontation between Kurds and Kazakhs that took place in 2007, at the majority-Kurdish village of Mayatas (in what is now the oblys of Turkestan), leading to demands for all Kurds to be expelled. ${ }^{83}$

78 All details as per the Barbang website: http://berbang-nur.com/?page_id=674 resp. https:// www.facebook.com/berbangkz.

79 Kurds of Kazakhstan, Historical Dictionary of Kazakhstan, Didar Kassymova, Zhanat Kudakbayeva, Ustina Markus, (Lanham, Toronto, Plymouth: Scarecrow Press, 2012), 167.

8o Nazarbaev progolosoval na vyborakh deputatov ot ANK, 11.1.2021, https://tengrinews.kz/ kazakhstan_news/nazarbaev-progolosoval-na-vyiborah-deputatov-ot-ank-42556o/.

81 Nadirov, Kurdy ochen' orosho.

82 Mirzoev interviewed by the magazine Liter, 20.4.20o6, published in Mirzoev, Kurdy, 325330, 329 .

83 Violence was meted out and houses burned down in reaction to unconfirmed reports of the rape of a Kazakh child by a Kurdish youth. The incident is reported as having deeply shaken all Kurds in Kazakhstan. Kazakstan: Ethnic Clash a Worrying Sign, 24.9.2007, https://iwpr.net/global-voices/kazakstan-ethnic-clash-worrying-sign. Reports then came in the summer of 2020 of another smaller interethnic clash between Kurds and Kazakhs in a village in the oblys of Zhambyl. Although peace appears to have been quickly restored, it created major waves in social media; Akim govorit, kak ne verit', Radio Azattyk, 12.8.2020, https://rus.azattyq.org/a/kazakhstan-kurds-kaskabulak-villageevents/30782329.html; Obrashchenie Prezidenta Assotsiatsiia ‘Barbang' po sobytii v pos. Kaskabulak Zhambylskoi oblasti, undated, http://berbang-nur.com/?p=2699. 


\section{Reconnecting with the World}

The Kurds are the largest stateless nation in the world. The attitude of the Uss R towards Kurds within its borders (and those in the Middle East) was ambivalent and changeful. Mustafa Barsani, the most prominent Kurdish leader of his day, was, for example, not greatly welcomed at the Kremlin when in 1947 he and his fighters sought political asylum in the Azeri ssR. Between 1923 and 1929, there was an Autonomous Kurdish Region enjoying special cultural and linguistic rights within the Azeri SSR in the territory between Nagorno-Karabakh and the Armenian ssR. This changed when the Kurds began to be deported from frontier regions in 1937. Amid considerable pressure to assimilate, many Kurds changed their ethnic affiliation. Beginning in the late 195os, Armenia then became a centre for the fostering of Kurdish identity. Radio broadcasts spread influence across borders into Kurdistan. ${ }^{84}$ However, it appears that no direct personal contacts across frontiers were possible, either to Kurdistan or the Kurdish diaspora in Europe. Nor do there seem to have been any notable contacts among Kurds living scattered across Soviet territory. The survival of their culture and language was in jeopardy..$^{85}$

This changed in the second half of the 1980s, when Kurds in the Soviet Union were swept up in a general 'nationalist fervor.' ${ }^{86}$ A large demonstration by Soviet Kurds took place in Moscow in 1989, with representatives from Kazakhstan and Central Asia taking part. In pursuit of their most important demand, the restoration of an autonomous territory (which for various reasons never took place ${ }^{87}$ ), they founded an ethnocultural organisation called Jakbun. One of its founding members, the oil engineer Nadir Nadirov, was a Kurd from Kazakhstan. Over the months and years that followed, Nadirov effectively

84 Pohl, 162; Martin van Bruinessen, 'Transnational aspects of the Kurdish question', Working Paper 2000/22 Robert Schuman Centre for Advanced Studies, European University Institute, https://www.researchgate.net/profile/Martin_Van_Bruinessen/publication/ 466o3119_Transnational_aspects_of_the_Kurdish_question/links/5c18b3b8a6fdcc494 ffca97c/Transnational-aspects-of-the-Kurdish-question.pdf?_sg\% $\%{ }_{5} \mathrm{~B} \circ \%{ }_{5} \mathrm{D}=\mathrm{KZH}$ 5qAmpphMbBZTd 7 PeoZdF 3 sSILDPkCEpBh868GPdfxJrvbgOQXLoQjVxhp4o-RSQ cmuzs8vEA_sGKYuaXFRg.WgcYjfQzuirOg6KtekMAEdM7PASIIGZRx-7tk5kybZ p8XVzqo3VxjwUDk9TqyA_qj3ZH3UkvhO2JF-mqQAG45w\&_sg\% ${ }_{5}$ B1 $_{3} \%{ }_{5} \mathrm{D}=\mathrm{Uo2}$ hadJV o5V99RdXWjgYUKSELcMl23osA2HecRixoU4vFoxQabj8ooJ43uiKdlpm_tiWgdTBTZx IfV 5 IgpriN6diogAvgFluHZj8yufZ42 2 Ot.WgcYjfQzuirOg6KtekMAEdM 7 PASIIGZRx -7tk5kybZp8XVzqo3VxjwUDkgTqyA_qj3ZH3UkvhO2JF-mqQAG45w\&_iepl=.

85 Nadir Nadirov, My, Kurdy—Kazakhstantsy, (Almaty: self-published, 2003), 275.

86 Ismet Chériff Vanly, 'The Kurds in the Soviet Union', in The Kurds. A contemporary overview, eds. Philip G. Kreyenbroek, Stefan Sperl, (London, New York: Routledge, 1992), 152172 , here 167 .

87 For more detail, see Manuel Hasratian, 'The Kurds of the USSR and the CIS (A Brief Account)', Iran and Caucasus 2, 1998, 39-47, here 42-6. 
became the international face of Soviet Kurds, appearing, for instance, at the first International Kurdish Conference in Paris in 1989-where he reminded the world's Kurds assembled there, as well as human rights experts and Kurdologists, of the existence of Kurds in the UssR and described their problems. ${ }^{88} \mathrm{He}$ also represented the Soviet Kurds at the first International Kurdish Conference in Moscow (1990). At the same time, he published two short articles in English-language periodicals concerning the situation of Kurds in the USSR, ${ }^{89}$ bringing him considerable authority (which persists to this day) in interpreting the situation and a degree of familiarity as a 'prominent Soviet Kurd. ${ }^{90}$

\section{Kurdistan as New Historical Homeland}

The last years of the USSR also saw the establishment of the first direct contact between Kurds living in the Soviet Union and those living in Kurdistan. Partly because of the failure to reestablish an autonomous region in Soviet territory and partly because of the UssR's collapse, these contacts led to a fundamental realignment, away from the idea of creating a real homeland in the territory of the former Soviet Union and towards commitment to the ideal Historical Homeland of Kurdistan. For the Kurds of Kazakhstan, likely due to the shared language (Kurmanji), contacts with the Turkish part of Kurdistan became very intensive very quickly, especially with the PKK (the Kurdish Workers' Party). These contacts were so close or striking that the Turkish press began publishing 'alarming reports' of PKK activities in Kazakhstan, warning that Kurds in Kazakhstan were being stirred up against Turkey. ${ }^{91}$

88 Sami Zubaida, 'Report from Paris. The Kurdish Conference', MERIP 163 (March/ April 199o), https://merip.org/199o/o3/report-from-paris-the-kurdish-conference/; 'Soviet Kurds "rediscovered" by Kremlin', Washington Post, October 17, 1989; https://www .washingtonpost.com/archive/politics/1989/10/17/soviet-kurds-rediscovered-by-kremlin/ d8951307-4198-41fd-9519-ea4937boa965/.

89 'What do the Soviet Kurds Want?', Asia and Africa Today 1991,1, 74-76; 'Population Transfer: A Scattered People Seeks Its Nationhood', Cultural Survival Quarterly Magazine, March 1992, https://www.culturalsurvival.org/publications/cultural-survival-quarterly/ population-transfer-scattered-people-seeks-its-nationhood.

$90 \quad$ Michael M. Gunter, 'Lachin', Historical Dictionary of the Kurds, online edition undated, no place of publication given, https://kurds_history.enacademic.com/347/Lachin.

91 Martin van Bruinessen, 'The impact of the dissolution of the Soviet Union on the Kurds.' Paper presented at the International Conference on Islam and Ethnicity in Central Asia, St Petersburg, 14-18 October, 1995, 1-12, 10, https://dspace.library.uu.nl/bitstream/ handle/1874/20692/bruinessen_95_impactofthedissolutionofthesovietunion.pdf ?sequence $=1$. 
During the 199os, the Kurds of Kazakhstan did not hesitate to support their newly discovered Historical Homeland and thereby oppose Turkey. More than 250 Kazakhstan Kurds demonstrated (without permission) at Almaty in 1995 during a visit by the then Turkish Prime Minister Tansu Ciler, protesting against human rights abuses and demanding the release of 'Kurdish patriots' in Turkey. They were restrained by police but were still able to hand a declaration to government representatives, demanding support for Kurds in Turkey. Two years later, when a planned Kurdish Nauryz celebration at Almaty, to which international guests had been invited, was banned at short notice, it was apparent to Kurdish participants that the Kazakhstan government had submitted to pressure from Ankara.

Angered, several thousand Kurds marched through Almaty. PKK flags and portraits of Abdullah Öcalan were said to have been on display. The Turkish foreign ministry sent an official protest note to the Kazakh government, saying that such incidents could not 'be allowed to take place in a country which has fraternal relations with Turkey.' ${ }^{92}$ The Öcalan case then made waves on two occasions in Almaty in 1999. A peaceful rally in reaction to his arrest in February escalated when about 2,ooo Kurds marched spontaneously through the city, an event that was unusual in Almaty in those days. OMON troops were deployed and demonstrators were arrested. ${ }^{93}$ In June of the same year, the announcement of the death sentence on Öcalan, which has never carried out, brought some 100 Kurds into the streets. Although the militia stopped them en route to the Turkish Embassy, it appears that there were no arrests. ${ }^{94}$ The Kurds say that difficulties over renewing the registration of their ethnocultural organisation were related to these events, ${ }^{95}$ but they were not hampered in their cultural work and were able to mark the 6oth anniversary of the deportation in November 1997 with a conference, exhibition, and concerts. An academic conference on the history and current situation of the Kurds took place in Almaty in 1999. Participants called on President Nazarbaev to use his great international authority to push for a just verdict in the Öcalan case. ${ }^{96}$ The first decade of the 21st century saw the Kurds not only to celebrating Nauryz unchallenged and in grand style, but also holding a press conference at Almaty on the occasion of the visit by Turkish President Recep Tayyip Erdoğan, informing the

92 Merhat Sharipzhan, Kazakhstan: Protest by Anti-Turkish Kurds Causes Embarrassment, 15.4.1997, https://www.rferl.org/a/1084329.html.

93 Nadirov, My Kurdy, 492.

94 Kurdskaya problema Kazakhstana.

95 Nadirov, My Kurdy, 311-3.

96 Ibid., 5 o1. 
public about the situation of the Kurds in Turkey. On February 15, 2003, a rally was held to mark the fourth anniversary of Öcalan's arrest. ${ }^{97}$

The Kurds of Kazakhstan were also active in demonstrating sympathy for the PKK on an international level. Nadir Nadirov, who was the head of Barbang from 1996 to 2003 and still remains its honorary chairman, was one of the founding members of the PKK-dominated Kurdish parliament-in-exile, like its current chairman, Mirzoev, of the Kurdish National Congress (founded in Amsterdam in 1999)..$^{98}$

The most recent appearance to date of reports of Kurdish activities in support of the PKK in 2007. For the first time in the history of independent Kazakhstan, 12 citizens had their citizenship revoked for taking up arms abroad. It was revealed at this point that, according to information from the KNB, around 40 Kazakhstani (not all Kurds) had emigrated between 1995 and 1999 to Iraq, Iran, Syria, and Turkey with the aim of fighting for a free Kurdistan. Six were killed and 20 returned to Kazakhstan. ${ }^{99}$ No further problematic activities by Kurds have been noted in recent years. It is striking, however, that both the honorary chairman of Barbang, Nadirov, who is a member of the governing Nur-Otan party, and the current chairman, Mirzoev, have recently made positive public statements about the PKK and Öcalan, while of course emphasising that there have been no contacts. Mirzoev has said that he himself is persona non grata in Turkey. 100

There is no doubt that these Kurdish activities are a burden on relations between the Republic of Kazakhstan and Turkey. ${ }^{101}$ The Kazakhstan leadership, however, seems not to have defined a clear position regarding Kurdistan until the first decade of the 2oth century. It is likely for this reason that the Kurdish minority long vested hopes in Nazarbaev's support. Now, however, Turkey is regarded as an important strategic and economic partner for the Republic of Kazakhstan ${ }^{102}$ and even a relatively powerful entity like Kazakhstan must submit to Turkey's demands. However, the idea that the Kurds of Kazakhstan have

$97 \quad$ Ibid., $535^{-6,} 5^{16 .}$

98 Ibid., 457. The Kazakhstan Supreme Court declared the National Congress a terrorist organisation in 2004.

99 Bez flaga, bez rodiny, 29.8.2007, https://time.kz/news/archive/2007/o8/29/531; Kurdskaya problema.

100 Mirzoev interview.

101 The Kurds of Kazakhstan are not alone in supporting the PKK. The Association of the Kurds in the former Soviet Union also tends in this direction.

102 'Turkey among Kazakhstan's key strategic partners', Azernews, 14.11.2019, https://www .azernews.az/region/158402.html; Algadaeva Zh., 'Dynamics of the development of KazakhTurkish relations at the present stage', Bulletin of Ablai Khan KazUIRandWL, 2017, https:// articlekz.com/en/article/19705. 
become 'hostages' in the bilateral relationship, as suggested by a Fergana News author in 2007 , is open for debate. ${ }^{103}$

The Kurds of Kazakhstan also, of course, took an active interest in events in the Kurdish regions of Iraq, Syria, and Iran. They even appealed personally to President Nazarbaev in 2017, asking him to intervene to protect Kurds in South Kurdistan (i.e., Iraq). ${ }^{104}$ The current chairman of Barbang proudly reported his meeting with Masud Barsani in the autumn of 2019. ${ }^{105}$ Unlike with Turkey, however, no foreign policy interests or frictions are (yet) apparent here. ${ }^{106}$

The youngest Kurdish representative quoted here, Vakil Nabiev, denies all connections with Kurds outside Kazakhstan. 'Honestly, the Kurds of Kazakhstan do not get involved with foreign politics, and whatever happens in the Near East is of no interest.'107

\section{Where Is the Homeland?}

Their commitment to the principle of Kurdish statehood, which is clearly one component, perhaps the most important component, of their identity, shows the Kurds of Kazakhstan to be typical of their global diaspora. ${ }^{108}$ The strong resultant emotional connection with Kurds in the traditional settlement regions is also expressed in the use of the pronouns 'we' and 'us.' Mirzoev, for instance, in an interview on the situation in Erbil in 2017, speaks of 'us' when referring to the Kurds in Iraq, and writes 'we are not separatists' (referring to Kurds in Turkey). ${ }^{109}$

Kurdistan, which, as late as 1991, played no role in the thinking of Kurds in Kazakhstan, is invariably called the Historical Homeland, without regard for current international frontiers and without distinction between north and south. According to Nabiev, there is unequivocally an indissoluble connection between Kurds and Kurdistan. He characterises this connection as a feeling of 'great love' for the homeland, even though the vast majority of them have never been there. ${ }^{110}$ Mirzoev has still not relinquished the dream of a free Kurdistan, and does not rule out the possibility of emigrating there, because it is his Historical Homeland. ${ }^{111}$

\footnotetext{
103 Kurdskaia problema.

104 Kurdy Kazakhstana prosiat u svoego Prezidenta pomoshchi, 23.10.2017, https://riataza .com/2017/10/23/kurdyi-kazahstana-prosyat-u-svoego-prezidenta-pomoshhi/.

105 Nadirov, My Kurdy, 440, 447.

106 There is no indication that Kurds from Kazakhstan took part in the Syrian peace negotiations initiated by the Republic of Kazakhstan.

107 Nabiev interview.

108 van Bruinessen, Transnational aspects, 4.

109 Mirzoev, Kurdy, 106.

110 Nabiev interview.

111 Mirzoev interview.
} 
Kazakhstan is usually called the 'Second Homeland', but a genuine one nonetheless, where Kurds were well received after deportation and are able to live an untroubled life as equal citizens. This strong identification with Kazakhstan depends, on the one hand, on international comparison ('in no other country on Earth do Kurds have so many rights and liberties as in Kazakhstan'112) and, on the other hand, on a comparison with the Historical Homeland, relative to which the Second Homeland necessarily appears in a good light. Kurds in Kazakhstan live in a 'civilised country.'113 In Turkish Kurdistan, I had the feeling of having regressed to the Stone Age. 'Even the huts we built in the years after our deportation to Kazakhstan were palaces in comparison to the shacks the Kurds inhabit in Turkey',114 said Nadirov, who had visited the Kurdish regions of Turkey in the 199os.

Despite all the commitment to Kurdistan, the Second Homeland seems to be far more of a preoccupation. As with the Chechens, place of birth is the crucial criterion. Mirzoev admitted this in his interview: 'For us who were born here and live here, Kazakhstan is our homeland. Home is where you were born and feel good.' Even the veteran Nadirov declares, 'Kurds sometimes start talking about the Historical Homeland, and I always correct them: "That is our ancestors' homeland. Your homeland is the place where you were born."'115 The much younger Nabiev in his interview even called Kazakhstan 'our first and only homeland', going on to explain, 'We have nowhere to emigrate to, so our destiny is completely bound up with the Republic of Kazakhstan.116 Even so, and as with the Chechens, there is an indissoluble biological link with Kurdishness - a gene — even if Kazakh has now become a Kurd's native language. ${ }^{117}$

Commitment to the Historical Homeland and a strong identification with Kazakhstan are even less mutually exclusive for the Kurds than for the Chechens. The former have developed a double identity even more pronounced than that of the latter. The Historical Homeland was redefined by the Kazakhstani Kurdish elite in the early 199os. It serves to connect Kazakhstan's Kurds with their global diaspora but is not an emigration option. Thus, they praise their Second Homeland Kazakhstan all the more.

\footnotetext{
112 Mirzoev, Kurdy, 323.

113 Nadirov, My Kurdy, 439.

114 Ibid., 441.

115 Ibid., 73 .

116 Nabiev interview.

117 Nadirov, My Kurdy, 73.
} 


\section{Conclusion}

Chechens and Kurds have not only accepted the offer implicit in Kazakhstani national policy to nurture active contacts with their Historical Homelands, but also made very proactive and independent use of it. Political commitments in support of an independent Chechnya, or demonstrations in support of Kurds in Turkey, were neither anti-Kazakhstani nor expressions of a lack of loyalty. At this period, the Kazakhstan leadership itself had no firm position on these issues or other struggles for freedom and independence. As that leadership became established, and as state control over the political and societal activities of citizens increased, the scope for ethnocultural organisations to undertake official activities in and on behalf of the Historical Homelands became more limited. This did nothing, however, to diminish trust in First President Nazarbaev as the protector of ethnicities' interests.

Although final proof of the grounds for the ban on PKK activities in Kazakhstan or paeans of praise for a Chechen Republic as part of the Russian Federation, will clearly have to wait for the opening of government archives, it is very probable that foreign-policy interests and constraints played an important part in the government's approach. This confirms that when homeland relations of ethnicities or diasporas lacking an independent home state are studied, the inclusion of a fourth component within a nexus, consequently no longer triadic but tetragonal, is both necessary and useful.

As early as 1997, a Kurd had already highlighted that the conflict was caused by the primacy of foreign and security policy interests at the expense of legitimate aspirations of home citizens as follows: 'Why is our government more concerned about relations with Turkey than with upholding the rights of its own citizens?'118 This conflict persists to this day, in regard not so much to Chechens and Kurds, but to Uighurs and even Kazakhs, as verdicts against activists protesting about Chinese reeducation camps make clear. It remains to be seen whether such experiences will have an impact on relations between the ethnicities studied here and Kazakhstan. ${ }^{119}$ Clearly, however, Chechens' and Kurds' ties to Kazakhstan are strong. Kurds' lack of an option to emigrate and Chechens' not uncomplicated situation in Chechnya should not be underestimated as factors here, just as political stability and above-average economic

118 Viktor Verk, Komu mozhno otmechat' Nauryza, AiF Kazkahstan March 1997, quoted from Nadirov, My Kurdy, 249.

119 Nor can anything be said here about the long-term effects of the violent interethnic conflicts of 2007, because the barriers to talking about these topics were too strong. 
development strengthen ties with Kazakhstan. ${ }^{120}$ Time also plays a part: forced resettlement now lies about 80 years in the past (i.e., four generations ago). Therefore, connection with the Second Homeland seems to grow.

This appears to indicate a shift in the dichotomous Kazakhstani concept of homeland. Representatives of both ethnic groups refer to Kazakhstan as their homeland, without the addition of 'Second' or 'Small.' Homeland appears as a constructed and idealised place of security and well-being. This observation, just like the question of the scale of this homeland, requires further research (opinion polls) among the broad masses of both ethnic groups. Their representatives undoubtedly understand this to mean the state of Kazakhstan in the broad sense and are thus responding to state expectations.

However, even the younger representatives of Chechen and Kurdish organisations still emphasise their apparently indissoluble, hereditary bond to the historical homeland, which is directly linked to the close, equally indissoluble bond to all members of their ethnic group. Conversely, to a Kazakh nationalist, a non-Kazakh fellow citizen, even if he has done military service and pays his taxes in Kazakhstan, is an object of suspicion who really belongs in 'his' Historical Homeland. The understanding of the term Historical homeland is thus linked to the primordial definition of ethnicity that dates back to the Soviet era. It would certainly be a step towards a more conflict-free coexistence among the ethnicities of the country if academics, politicians, and the wider public overcame the Soviet era in this respect as well.

120 This multiple identity seems to be typical not only of ethnic groups with a problematic historical homeland. Davenel has also found it among the Tatars of Kazakhstan and Sanders among Germans who had decided against emigration. See Yves-Marie Davenel, 'Are National Minorities of the Former USSR Becoming New Diasporas? The Case of the Tatars of Kazakhstan', Diasporas. Critical and Inter-Disciplinary Perspectives, ed. Jane Fernandez, (Oxford: The Interdisciplinary Press 2009), 75-85, 81; Sanders, 309. 